\title{
Anger at halal law imperils German research
}

Quirin Schiermeier and Marion Kerstholt Germany is poised to pass a constitutional amendment that may lead to tighter restrictions on the use of animals in research.

Following a policy reversal by the main opposition party, the constitution is likely to be modified this year to state that animals must be treated as fellow creatures and protected from avoidable pain.

Such an amendment has been backed for several years by the governing Social Democrat and Green parties, but its passage by the required two-thirds majority was blocked by the opposition Christian Democrats.

The Christian Democrat leaders now say they support the amendment. According to party leader Angela Merkel, the change is linked to a controversial judgement by Germany's highest court on halal slaughtering. The court ruled in January that Muslims, like Jews, should be allowed to slaughter animals in this way. In this form of slaughtering, the animal is not stunned before it is killed.

The judgement has been badly received by the German public, and animal-welfare groups such as the Deutsche Tierschutzbund have intensified their campaign to change the constitution. But scientists fear that the proposed bill will interfere with their right to carry out research - which is separately enshrined in the constitution.

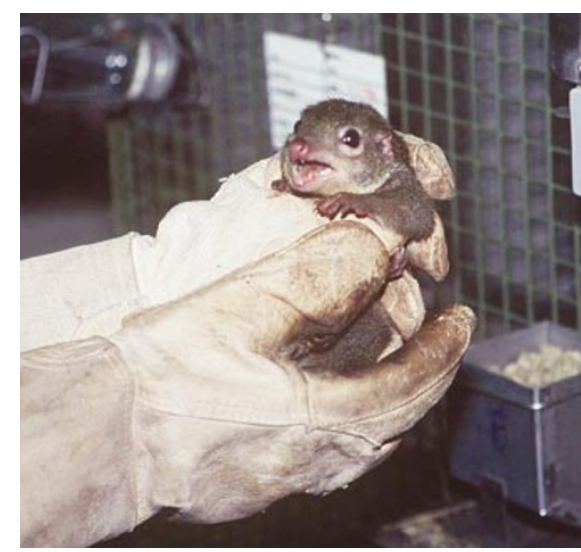

Hands off: work on animals such as this specially bred tupaia (tree shrew) may become illegal.

Germany's animal-protection laws are already among the strictest in the world, and until now science organizations have successfully campaigned against additional restrictions (see Nature 397, 461; 1999).

Research organizations criticize the Christian Democrats' shift on the issue. "This will create huge problems for basic and industrial research," says Ivar Aune, a spokesman for the Society for Health and Research, Germany's main lobby group for biomedical research. "The requirement of weighing freedom to research and animal rights is likely to lead to endless legal arguments and further bureaucratic obstruction to research involving animals."

Animal-protection groups expect the amendment to become a strong legal tool for them. "We will do everything in our power to reduce the number of experiments in Germany," says Wolfgang Apel, president of the Deutsche Tierschutzbund. "The constitutional freedom to research will no longer be enough to legally justify the use of animals in research," he predicts.

Andreas Kreiter, a neuroscientist at the University of Bremen, who uses macaques for his studies of electrical signals in primate brains, has been verbally and physically attacked by activists (see Nature 396, 505; 1998). Kreiter says that the amendment "would further threaten" his work.

But researchers now seem to be resigned to its passage in some form before October's elections. "The halal judgement has sensitized the public to an extent that a constitutional amendment seems unavoidable," says Kuno Kirschfeld, director of the Max Planck Institute for Biological Cybernetics in Tübingen, who deals with animal welfare at the Max Planck Society. "We are very unhappy about this development", he says, "but it looks as if all we can do is campaign for soft wording."

\section{Alternative therapies leave US commission divided}

\section{Erika Check, Washington}

A White House panel has failed to reach agreement on the awkward question of how to deal with alternative medicine.

The majority of the White House Commission on Complementary and Alternative Medicine Policy, set up two years ago by President Bill Clinton, has called for the health department to establish a powerful new office to coordinate research and information on 'alternative' treatments such as homeopathy and acupuncture.

But a minority of members has written a statement of dissent - and is instead calling on the government to do more to highlight scientific scepticism about these therapies.

The Bush administration may choose to ignore the findings, which were received by the health department earlier this month and will be passed on to the White House shortly. But although disparaged by many scientists and doctors, alternative medicine is reported to be used by $42 \%$ of Americans (D. M. Eisenberg et al. J. Am. Med. Assoc. 280, 1569-1575; 1998).

The therapies' fans include Senator Tom Harkin (Democrat, Iowa), who chairs the
Senate panel responsible for funding public health and biomedical research.

The panel was chaired by James Gordon of Georgetown Medical School, director of the Center for Mind-Body Medicine in Washington. Its majority report calls for the government to increase its support for research into alternative medicine. The report adds that "safe and effective" alternatives should be paid for by federal health programmes, such as Medicaid, and that the government should provide incentives for private companies to research natural therapies that cannot be patented.

But two members - Joseph Fins of the Weill Medical College of Cornell University, and Tieraona Low Dog, medical director of the Tree House Center of Integrative Medicine in Alberquerque, New Mexico filed a dissenting statement. "We felt we needed to give voice to some of the healthy scepticism that exists with regard to complementary and alternative medicines in many areas of American life," Fins says. He adds that the main report spent too much time advocating its subject and failed to justify its call for more research money.
Fins also says that the National Center for Complementary and Alternative Medicine, a branch of the National Institutes of Health, should fund most research on unorthodox therapies. The majority's report suggests that the government should distribute more research dollars for complementary medicine to several agencies.

Health department spokesman Bill Hall says that it is too early to know what the administration will do with the findings.

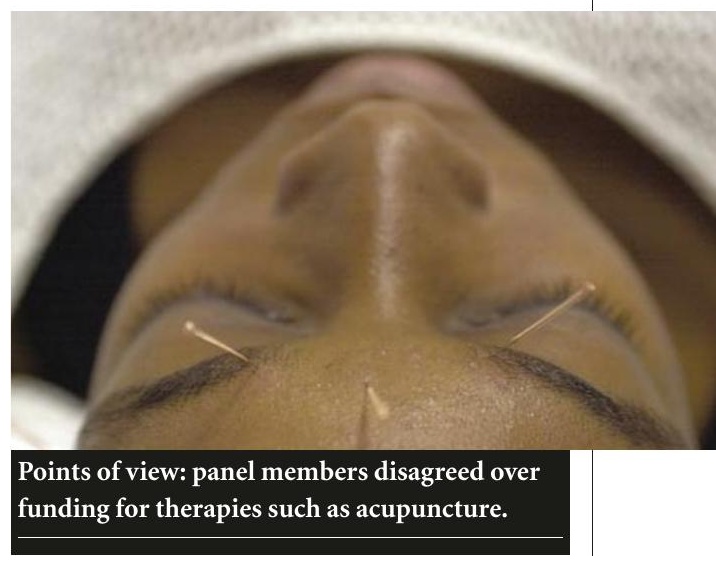

